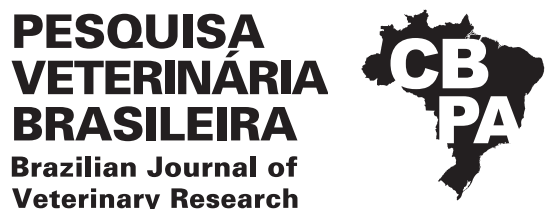

Pesq. Vet. Bras. 41:e06856, 2021

DOI: 10.1590/1678-5150-PVB-6856

Original Article

Veterinarv Research

ISSN 0100-736X (Print)

Livestock Diseases

ISSN 1678-5150 (Online)

\title{
Clinical, laboratory and anatomopathological study of caudal vena cava thrombosis in cattle ${ }^{1}$
}

\author{
Luiz T. Coutinho ${ }^{2 *} \mathbb{D}$, Jomel F. Santos ${ }^{3}$, Rodolfo José C. Souto ${ }^{4}$, Nivan A.A. Silva², \\ José Cláudio A. Souza ${ }^{5}$, Carla L. Mendonça² ${ }^{2}$ Jobson Filipe P. Cajueiro ${ }^{4}$ (D) \\ and José Augusto B. Afonso ${ }^{2}$
}

\begin{abstract}
Coutinho L.T., Santos J.F., Souto R.J.C., Silva N.A.A., Souza J.C.A., Mendonça C.L., Cajueiro J.F.P. \& Afonso J.A.B. 2021. Clinical, laboratory and anatomopathological study of caudal vena cava thrombosis in cattle. Pesquisa Veterinária Brasileira 41:e06856, 2021. Clínica de Bovinos de Garanhuns, Av. Bom Pastor s/n, Garanhuns, PE 55292-270, Brazil. E-mail: coutinholtc@gmail.com

This paper aimed to describe the main clinico-epidemiological, laboratory, and anatomopathological findings in 10 cattle affected with caudal vena cava thrombosis. The main clinical signs observed were decreased milk production, reduced appetite, apathy, impairment of ruminal motility, cardiorespiratory disorders (tachycardia and tachypnea), epistaxis, hemoptysis, and ascites. Intercurrent diseases such as mastitis, metritis, and phlebitis were verified. The hematological findings were mild anemia, leukocytosis due to neutrophilia with regenerative left shift, and hyperfibrinogenemia. The pathological exams revealed thrombi in the caudal vena cava, hepatomegaly, ascites, liver abscesses, pulmonary edema and emphysema, and abscesses in the lungs. The association of epidemiological information, clinical signs such as respiratory distress, epistaxis or hemoptysis, in addition to anemia and leukocytosis due to neutrophilia, as well as the occurrence of thrombus in the caudal vena cava as pathological findings, are indicative elements of the clinical picture of vena cava thrombosis in cattle. It is reiterated that this disease has an unfavorable prognosis and, when diagnosed, the animal must be culled.
\end{abstract}

INDEX TERMS: Clinics, anatomopathology, thrombosis, cattle, liver disease, vascular disease, ruminants, thromboembolism, vena cava.

RESUMO.- [Estudo clínico, laboratorial e anatomopatológico da trombose da veia cava caudal em bovinos.] Este trabalho teve por objetivo descrever os principais achados clínicoepidemiológicos, laboratoriais e anatomopatológicos de 10 bovinos diagnosticados com trombose da veia cava caudal.

\footnotetext{
${ }^{1}$ Received on June 2, 2021.

Accepted for publication on July 2, 2021.

${ }^{2}$ Clínica de Bovinos de Garanhuns (CBG), Pró-reitoria de Pesquisa e Pós-Graduação, Universidade Federal Rural de Pernambuco (UFRPE), Av. Bom Pastor s/n, Boa Vista, Garanhuns, PE 55292-270, Brazil. E-mails: nivanvet@yahoo.com.br, carlalopes.mendonca@gmail.com, afonsojab@gmail.com; *Corresponding author: coutinholtc@gmail.com

${ }^{3}$ Graduate Program in Health and Ruminant Reproduction, Unidade Acadêmica de Garanhuns (UAG), Universidade Federal Rural de Pernambuco (UFRPE), Av. Bom Pastor s/n, Boa Vista, Garanhuns, PE 55292-270, Brazil. E-mail: jomel.santos@ifam.edu.br

${ }^{4}$ Clínica de Bovinos de Garanhuns (CBG), Universidade Federal Rural de Pernambuco (UFRPE), Av. Bom Pastor s/n, Boa Vista, Garanhuns, PE 55292270, Brazil.E-mails: rodoufo.souto@hotmail.com, jobson.filipe@gmail.com

${ }^{5}$ Curso de Medicina Veterinária, Unidade Acadêmica de Garanhuns (UAG), Universidade Federal Rural de Pernambuco (UFRPE), Av. Bom Pastor s/n, Boa Vista, Garanhuns, PE 55292-270, Brazil.
}

Os principais achados clínicos foram redução da produção leiteira, diminuição do apetite, apatia, comprometimento da dinâmica ruminal, alterações cardio-respiratórias (taquicardia e taquipnéia), epistaxe, hemoptise e ascite. Foi constatada a ocorrência de doenças intercorrentes como mastite, metrite e flebite. 0 hemograma revelou discreta anemia, leucocitose por neutrofilia com desvio para esquerda regenerativo e hiperfibrinogenemia. No exame anatomopatológico revelou trombos localizados na veia cava caudal, hepatomegalia, ascite e abscessos hepáticos; além de abscessos, enfisema e edema pulmonares. A associação de informações epidemiológicas, sinais clínicos como desconforto respiratório, epistaxe ou hemoptise, além de anemia e leucocitose por neutrofilia, bem como a ocorrência de trombo na veia cava caudal como achados patológicos são elementos indicativos do quadro clínico de trombose de veia cava em bovinos. Reitera-se que essa doença tem prognóstico desfavorável e, quando diagnosticada, o animal deve ser abatido.

TERMOS DE INDEXAÇÃO: Clínica, anatomopatologia, trombose, bovinos, doença hepática, doença vascular, ruminantes, tromboembolismo, veia cava. 


\section{INTRODUCTION}

The caudal vena cava thrombosis (CVCT) is a disease of low occurrence, but well described in cattle (Braun et al. 2002, Wilkins \& Woolums 2015). It is most commonly associated with rumenitis and/or abomasitis, favoring bacteria to reach the hepatic portal system, which may lead to formation of liver abscesses (Nagaraja \& Lechtenberg 2007, Peek \& Divers 2018), and subsequently, depending on the proximity of the abscesses to the caudal vena cava to thrombi in this vessel. The formation of these thrombi may also be the consequence of other septic conditions, such as phlebitis, mastitis, metritis, traumatic reticulitis, omphalophlebitis, and pododermatitis (Gudmundson et al. 1978, Plaizier et al. 2008, Wilkins \& Woolums 2015).

CVCT is a significant clinical problem for livestock, with major economic consequences, especially for dairy farming (Breeze et al. 1976, Simpson et al. 2012). Clinically, the disease manifests itself as a respiratory syndrome due to thromboembolism of the pulmonary artery, with formation and rupture of pulmonary arterial aneurysms. Increased abdominal distention due to hepatomegaly and ascites, as well as sudden death after severe intrapulmonary hemorrhage or hemoptysis, are rare but can occur (Selman et al. 1974, Breeze et al. 1976, Braun 2008, Tharwat 2010, Braun et al. 2016). In Brazil, occasional cases of this syndrome have been reported in dairy cattle (Afonso et al. 2001, Facury Filho et al. 2007, Carneiro et al. 2019).

Because of its importance and clinical complexity, this paper aimed to describe the main epidemiological, clinical, hematological, biochemical, and anatomopathological findings in 10 cattle affected with thrombosis of the caudal vena cava.

\section{MATERIALS AND METHODS}

A retrospective study of medical records was performed in the "Clínica de Bovinos de Garanhuns”, "Universidade Federal Rural de Pernambuco" (CBG-UFRPE), Brazil, from January 2007 to February 2015. Clinical, epidemiological (age, breed, sex, production system, food type), laboratory, and anatomopathological information from ten cattle diagnosed with CVCT was investigated. All cattle attended had a history of decreased appetite, rumination and milk production; some of them had respiratory signs (fatigue), reduced fecal production and progressive abdominal distention.

One of the affected animals was dead on admission to the clinic and was sent directly to necropsy. The other nine cattle were submitted to clinical examination (Dirksen 1993). Blood samples from eight animals were collected for laboratory examination by jugular vein puncture into vacuum tubes containing 10\% EDTA for a complete blood count (CBC) and determination of total plasma protein and fibrinogen (Jain 1986). Five of the animals submitted to a clinical examination died, and because of the poor prognosis, the other four cattle were euthanized (Luna \& Teixeira 2007) and necropsied. Samples were not processed for histopathological and bacteriological examination.

\section{RESULTS}

For the given period of eight years, the ratio of CVCT in cattle was approximately $0.25 \%(10 / 4044)$, with a higher prevalence in dairy cows (80\%) and males (20\%), older than three years $(>3$ years $=3,>4$ years $=7$, Average $=4$ and Median $=4)$ and reared in semi-intensive $(70 \%)$ or intensive $(20 \%)$ or extensive (10\%) production systems. Five of the animals were Holstein, four were crossbred Holstein-Zebu cattle and one was Jersey. Of the cows, eight were not pregnant, four were lactating in the first quarter of production, two were dry and two without production information. The animals $(70 \%)$ were fed a diet composed only of soybean and corn meal, consumed an average of 6-8kg per day, in addition to forage, corn silage, sugarcane silage, spineless cactus, cottonseed meal and agribusiness residues such as cassava bark, sugar cane bagasse, brewery residue and poultry litter. Around $80 \%$ of the animals received mineral mixture.

On admission, in nine cattle diagnosed with CVCT, the most important sign was a body condition moderate to thin and dehydration in all the cattle and apathy. In four cows, the mucous membranes were pale. The temperature was within the normal range for the species. There was tachycardia in seven animals. There was tachypnea in six animals and there was dyspnea. Pulmonary changes with breathing difficulties were observed, five cattle had a spontaneous cough and crackles, four grunting's, two had areas of silence. Three animals had abdominal breathing. Of nine cattle, five had serous to catarrhal nasal discharge (broncopulmonary origin). Two had bilateral epistaxis and one of these also had bleeding from the mouth (Fig.1 and 2). Appetite and ruminal motility were reduced or absent in seven cattle. One cow had a distended, pear-shaped abdomen. Test for reticular foreign bodies was negative (percussion in the xiphoid region and withers pinching). The occurrence of complications such as clinical mastitis (non-suppurative), metritis (mucupurulent secretion) and phlebitis (suppurative) in four animals was also reported. The clinical evolution time was less than 20 days in nine animals, only one showed an evolution of 90 days. Of the affected animals, only two were treated with antibiotics (penicillin, florfenicol), non-steroidal anti-inflammatory (flunexin-meglumine) and secretolytic (bromhexine), for one day and three days, respectively, without satisfactory results, and died.

The results of the hematological exams, in eight cattle, demonstrated that three had anemia and four had a leukocytosis by neutrofilia with a left shift. In five cattle the concentration of fibrinogen was higher than normal (Table 1).

The anatomopathological findings in this study were thrombi of different sizes in the caudal vena cava (minimum $3 \mathrm{~cm}$ and maximum $25 \mathrm{~cm}$ ), attached to the intima and partially or completely occluding the lumen, looking like an elongated whitish-yellow structure. The thrombi were usually located in the hepatic portion of the caudal vena cava. In one case the thrombus was located cranial to the liver, occluding the whole vessel lumen, which presented a severe degree of ascites and with approximately 120 liters of peritoneal fluid light brown, clear, non-malodorous was removed at necropsy (Fig.3-6). The livers were enlarged, firmer than normal and had an irregular surface, and abscesses were present in $80 \%$ of the cases, some $(\mathrm{n}=5)$ of them situated adjacent to the caudal vena cava, in an advanced stage of maturation, rupturing into the vein (Fig.7 and 8). Five animals had bronchopneumonia and multiple pulmonary abscesses. In two cows the lungs were also filled with blood, and in seven, there was severe pulmonary emphysema and edema in four (Fig.9 and 10) (Table 2). In other organs, no significant pathological findings were found. 


\section{DISCUSSION}

In Brazil, some cases of CVCT in cattle have been reported and related to various inflammatory and/or septic conditions (Afonso et al. 2001, Facury Filho et al. 2007, Santos et al. 2015, Motta et al. 2016, Carneiro et al. 2019).

The ratio of $0.25 \%(10 / 4044)$ of CVCT in this study was lower than those reported by Gudmundson et al. (1978), ranging from $1.3 \%$ to $4.35 \%$. The profile of the most commonly affected cattle (dairy female aged over four years), also diverges from the findings of Gudmundson et al. (1978) and Constable et al. (2017), who observed a higher incidence of the disease in beef cattle, with no predilection for breed, age, or sex. Liver abscesses are the most common cause of thrombosis of the caudal vena cava in cattle, in this work is justified by the fact that the current study was conducted in a dairying region with a higher number of dairy cows exposed to potential risk factors for the disease, such as intensive feed management, which predisposes cattle to various digestive disorders, including ruminal acidosis and others that can also cause emboli from inflammatory processes in other organs, such as the udder, uterus or claws (Braun 2008, Constable et al. 2017), however, in this study no specific lesions in the rumen were observed.

The diagnosis of CVCT in live animals is difficult because most animals present nonspecific clinical signs: poor general
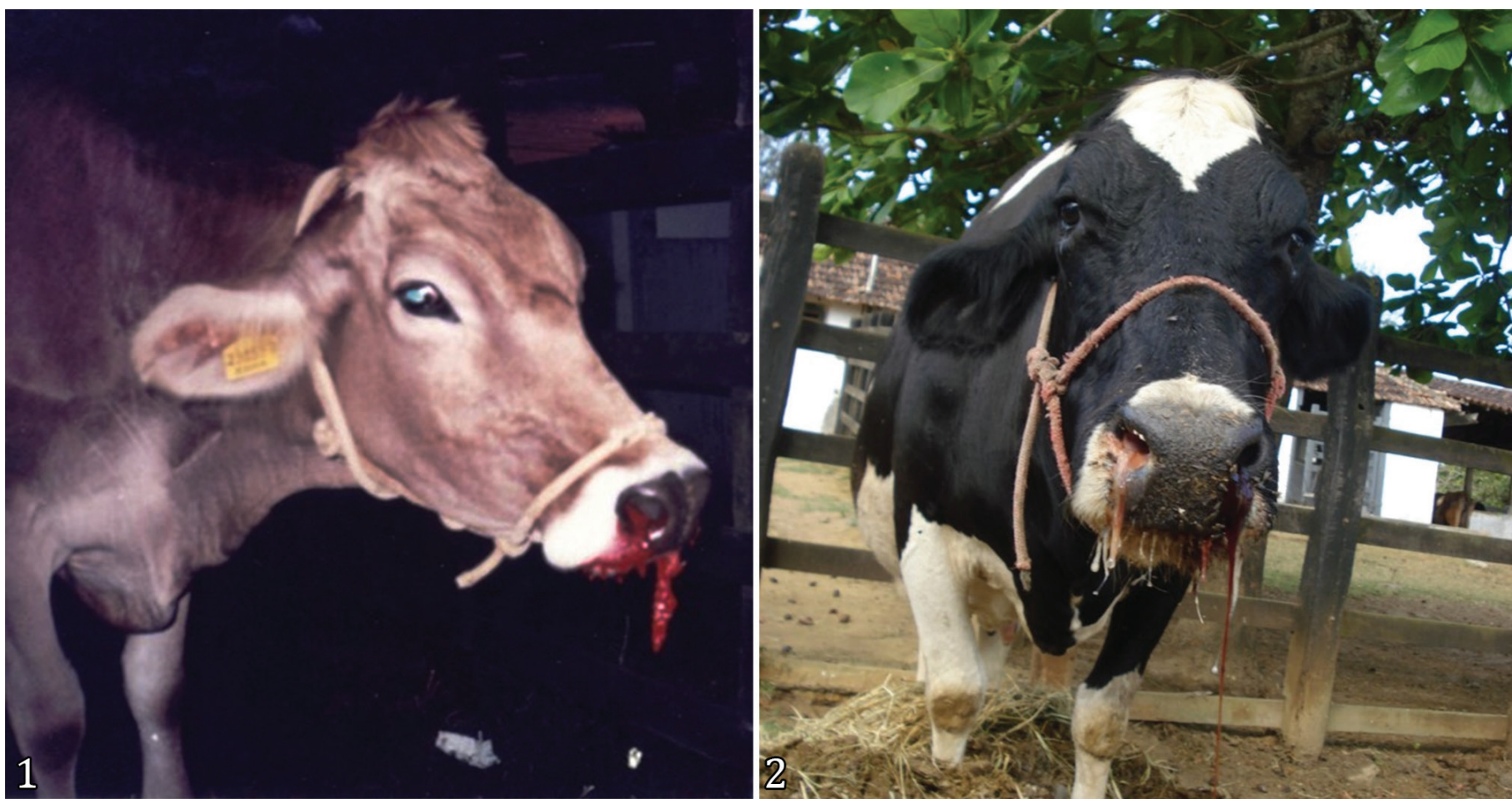

Fig.1-2. Thrombosis of the caudal vena cava in cattle. (1) Case 1 and (2) case 8: bovines with epistaxis and hemoptysis in both nostrils.

Table 1. Haematological findings in cattle $(n=8)$ diagnosed with thrombosis of the caudal vena cava at CBG-UFRPE from January 2007 to February 2015

\begin{tabular}{|c|c|c|c|c|c|c|c|c|c|c|}
\hline Parameters & Case 1 & Case 2 & Case 3 & Case 4 & Case 5 & Case 6 & Case 7 & Case 8 & Average & Reference values $^{\mathrm{e}}$ \\
\hline Hematocrit (\%) & 21 & 26 & 18 & 27 & 14 & 27 & 30 & 31 & 24.3 & 24 to 46 \\
\hline Erythrocytes $\left(\mathrm{x} 10^{6} / \mu \mathrm{L}\right)$ & 5.31 & 5.3 & 3.52 & 5.8 & 3.25 & 5.63 & 7.83 & 6.89 & 5.4 & 5 to 10 \\
\hline Hemoglobin (g/dL) & - & 8.05 & 5.98 & 9.4 & 4.34 & 9.72 & 8.4 & 10.43 & 8.0 & 8 to 15 \\
\hline $\operatorname{MCV}(f L)^{a}$ & 39.5 & 49.05 & 51.13 & 46.57 & 43.08 & 47.95 & 38.31 & 44.99 & 45.1 & 40 to 60 \\
\hline $\mathrm{MCHC}(\%)^{\mathrm{b}}$ & - & 30.96 & 33.22 & 34.8 & 31 & 36 & 28 & 33.6 & 32.5 & 30 to 36 \\
\hline $\operatorname{STP}(\mathrm{g} / \mathrm{dL})^{\mathrm{c}}$ & 8.2 & 9.8 & 9.0 & 9.9 & 5.4 & 9.5 & 5.6 & 7.4 & 8.1 & 7 to 8.5 \\
\hline $\mathrm{SF}(\mathrm{mg} / \mathrm{dL})^{\mathrm{d}}$ & 1,100 & 800 & 600 & 1,400 & 900 & 1,400 & - & 600 & 971.4 & 300 to 700 \\
\hline Total leukocytes $(/ \mu \mathrm{L})$ & 51,900 & 9,450 & 13,500 & 18,550 & 6,500 & 10,400 & 10,000 & 30,900 & $18,900.0$ & 4,000 to 12,000 \\
\hline Neutrophils $(/ \mu \mathrm{L})$ & 48,756 & 3,686 & 7,830 & 13,727 & 3,185 & 6,968 & 5,800 & 0 & $12,750.4$ & 600 to 4,000 \\
\hline Lymphocytes $(/ \mu \mathrm{L})$ & 3,114 & 5,481 & 5,535 & 4,452 & 1,235 & 2,496 & 4,000 & 0 & $5,568.0$ & 2,500 to 7,500 \\
\hline Monocytes $(/ \mu \mathrm{L})$ & 0 & 189 & 135 & 927 & 0 & 520 & 100 & 0 & 272.5 & 25 to 840 \\
\hline Eosinophils $(/ \mu \mathrm{L})$ & 0 & 0 & 0 & 188 & 0 & 104 & 0 & 0 & 75.1 & 0 to 2,400 \\
\hline Metamyelocytes $(/ \mu \mathrm{L})$ & 0 & 0 & 0 & 0 & 65 & 0 & 0 & 0 & 8.1 & 0 \\
\hline Rods $(/ \mu \mathrm{L})$ & 0 & 95 & 0 & 0 & 2.015 & 312 & 100 & 0 & 315.3 & 0 to 120 \\
\hline
\end{tabular}

${ }^{a}$ Mean corpuscular volume, ${ }^{b}$ mean corpuscular hemoglobin concentration, ${ }^{c}$ plasma proteins, ${ }^{\mathrm{d}}$ plasma fibrinogen, ${ }^{\mathrm{e}} \mathrm{Krammer}(2000)$. 
condition, tachycardia, tachypnoea, and abnormal lung sounds, among other symptoms that can be attributed to other diseases (Braun et al. 2002, Tharwat 2010). Respiratory distress was observed in six animals, however, more severe symptoms such as epistaxis or hemoptysis were observed in two animals, in addition to conditions such as chronic pneumonia and anemia, these findings being compatible with the manifestation of the disease, as described by Braun (2008) and Peek \& Divers (2018). These signs, also reported by Motta et al. (2016) characterize the classic form of CVCT and are most widely observed in the terminal stage of the disease (Mills \& Pace 1990, Mohamed et al. 2004, Peek \& Divers 2018). Sudden death and acute respiratory distress can occur (Selman et al. 1974, Braun 2008, Wilkins \& Woolums 2015, Peek \& Divers 2018).

The abdominal enlargement observed in one animal, in the present study, is consistent with the mild ascites observed in another's paper (Braun et al. 1992, Braun 2008). For these authors, ascites associated with CVCT is rare and only develops when the thrombus is located cranial to the liver, occluding at least half of the vena cava lumen or where there is compression of the caudal vena cava by liver abscesses and causes portal hypertension (Braun et al. 2016, Peek \& Divers 2018).
The changes observed in the hemogram such as anemia, leukocytosis due to neutrophilia with regenerative left shift, and hyperfibrinogenemia were also observed by Mohamed et al. (2004), Constable et al. (2017), Braun (2008), and Tharwat (2010). This finding is suggestive of inflammation and/or infection (Braun 2008, Peek \& Divers 2018), and when associated with the clinical conditions denotes a poor prognosis, since all the affected animals died or were euthanized in extremis.

The thrombi in the caudal vena cava is considered one of the main anatomopathological records in cattle with CVCT (Breeze \& Petrie 1977, Tharwat 2010, Gerspach et al. 2011) and was observed in all animals in this study. This was also reported by Braun (2008) in all necropsies on animals suspected of CVCT; however, Gudmundson et al. (1978) registered a lower rate of thrombus. In cattle suspected of having thrombosis of the vena cava, CVC criteria for the autopsy are needed and the post mortem examination should be performed before the liver is removed from the carcass, since during the liver removal, the thrombus or part of it can be easily missed (Braun 2008).

Other pathological lesions observed in the liver (abscesses and hepatomegaly) and in the lungs (emphysema, abscesses, edema,
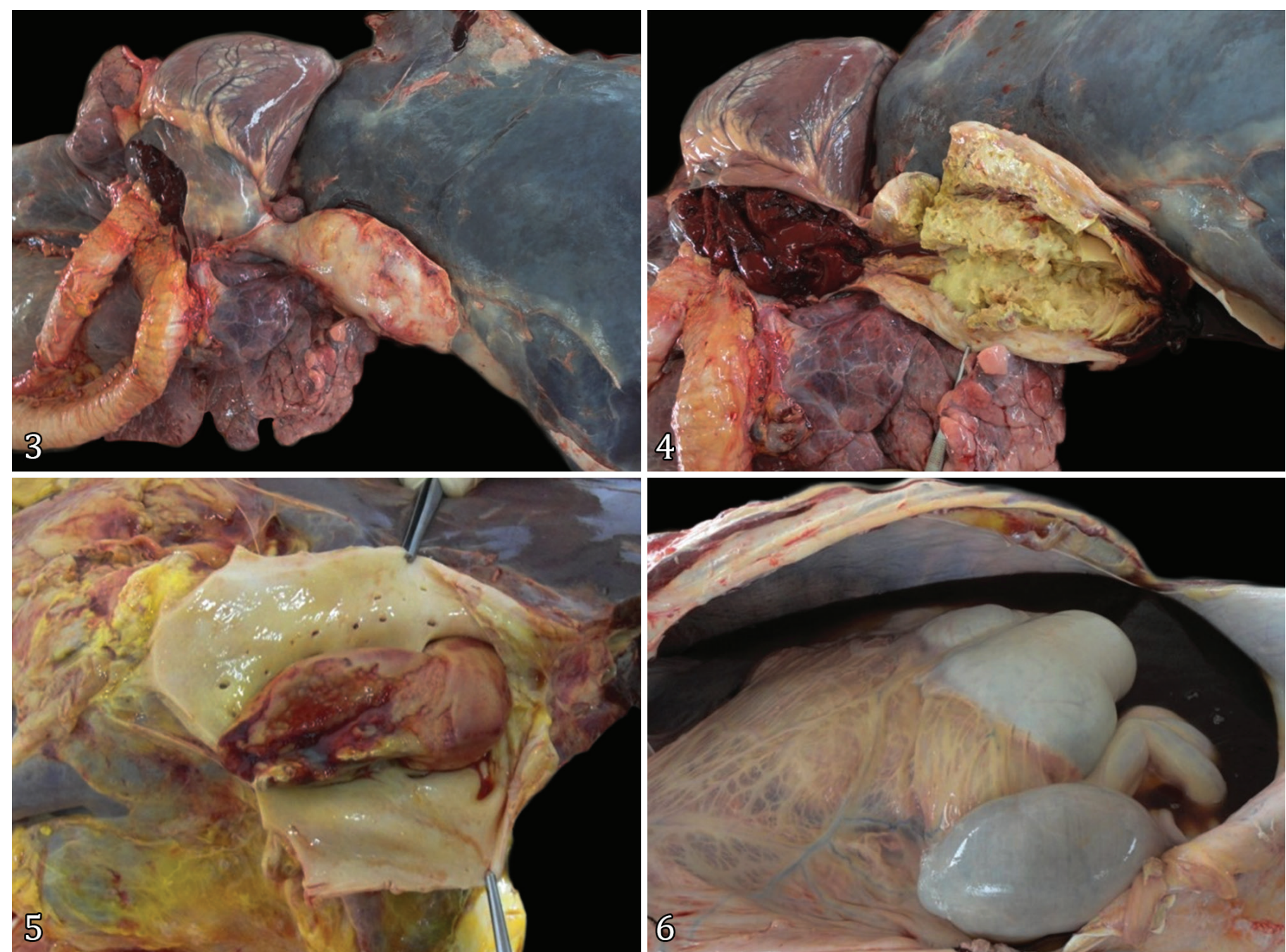

Fig.3-6. Thrombosis of the caudal vena cava in cattle. $(3,4)$ Case 5 and $(5)$ case 7 : thrombi obstructing the lumen of the caudal vena cava. (6) Case 5: ascites. 
and congestion) of cattle affected by CVCT were qualitatively and quantitatively consistent with those reported by other authors (Gudmundson et al. 1978, Braun 2008). The majority of these lesions, liver abscesses in particular, are sequela related

Table 2. Anatomopathological findings in cattle $(n=10)$ diagnosed with thrombosis of the caudal vena cava at CBGUFRPE from January 2007 to February 2015

\begin{tabular}{lcc}
\hline \multicolumn{1}{c}{ Site of lesions } & Lesions & Frequency \\
\hline Abdominal cavity & Peritonitis & $4 / 10(40 \%)$ \\
& Ascites & $2 / 10(20 \%)$ \\
Liver & Emphysema & $1 / 10(10 \%)$ \\
& Hepatomegaly & $5 / 10(50 \%)$ \\
Thoracic cavity & Abscesses & $8 / 10(80 \%)$ \\
& Nutmeg appearance & $3 / 10(30 \%)$ \\
& Pleurisy & $4 / 10(40 \%)$ \\
& Pulmonary emphysema & $7 / 10(70 \%)$ \\
Caudal vena cava & Pulmonary abscess & $5 / 10(50 \%)$ \\
& Pulmonary oedema & $4 / 10(40 \%)$ \\
& Hemorrhage in the heart & $4 / 10(40 \%)$ \\
& Thrombus & $10 / 10(100 \%)$
\end{tabular}
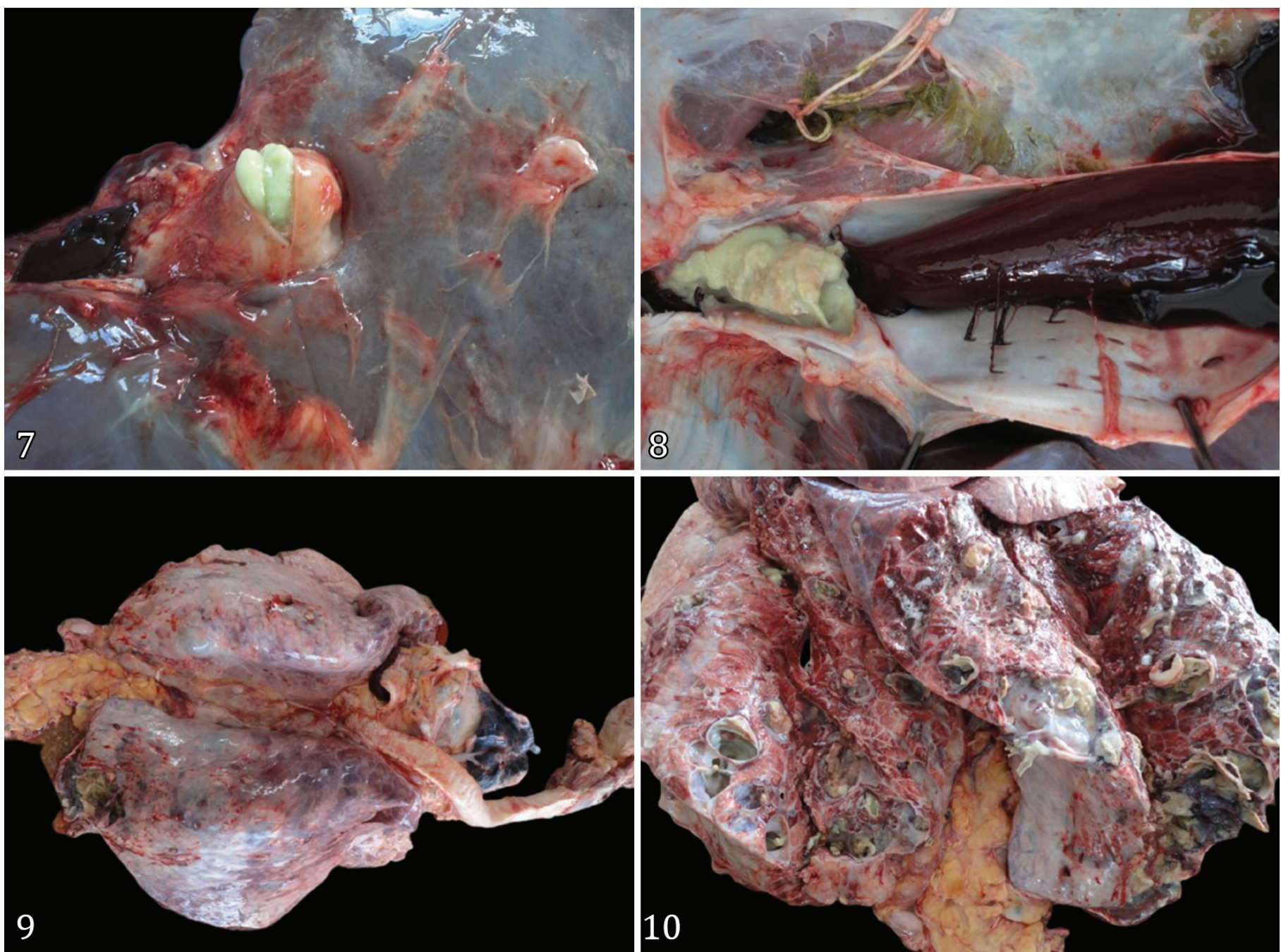

Fig.7-10. Thrombosis of the caudal vena cava (CVCT) in cattle. $(\mathbf{7 , 8})$ Case 8: liver abscesses contiguous to the caudal vena cava. $(\mathbf{9 , 1 0})$ Case 8: abscess pneumonia in cattle affected by CVCT. to rumenitis/abomasitis which are caused by ruminal acidosis (Gudmundson et al. 1978, Nagaraja \& Lechtenberg 2007, Vechiato et al. 2011, Constable et al. 2017). However, concurrent diseases to CVCT such as mastitis, metritis, and phlebitis were observed in the current study and cannot be discarded as a potential cause of the primary focus of CVCT (Mohamed et al. 2004, Plaizier et al. 2008, Wilkins \& Woolums 2015).

The site of the liver abscesses observed in this study, located adjacent to the caudal vena cava, was similar to reports from other authors (Gudmundson et al. 1978, Braun et al. 2016). From the pathophysiological point of view this location is particularly important due to its proximity to the vena cava, since there is a higher risk of spreading emboli and/or microorganisms (Monlux 1962, Peek \& Divers 2018).

\section{CONCLUSION}

The association of epidemiological information such as confined or semi-confined dairy cows submitted to a high energy density diet, presenting clinical signs such as respiratory distress, associated with epistaxis or hemoptysis, in addition to anemia and leukocytosis due to neutrophilia, as well as the occurrence of thrombus in the caudal vena cava as pathological findings are 
indicative elements of the clinical picture of vena cava thrombosis in cattle. It is reiterated that this disease has an unfavorable prognosis and, when diagnosed, the animal must be culled.

Acknowledgements.- The authors would like to thank the "Clínica de Bovinos de Garanhuns", "Universidade Federal Rural de Pernambuco” (CBG-UFRPE) for the necessary conditions to carry out this work.

Conflict of interest statement.- None of the authors have any financial or personal relationships that could inappropriately influence or bias the content of the paper

\section{REFERENCES}

Afonso J.A.B., Costa N.A., Mendonça C.L., Souza M.I., Coutinho L.T., Simão L.C.V. \& Pires Jr J.B. 2001. Tromboembolismo da artéria pulmonar com trombose da veia cava caudal em uma vaca. Relato de caso. Ciênc. Vet. Tróp. 4(2/3):310-314.

Braun U. 2008. Clinical findings and diagnosis of thrombosis of the caudal vena cava in cattle. Vet. J. 175(1):118-125. <https://dx.doi.org/10.1016/j. tvjl.2006.11.013><PMid:17239635>

Braun U., Fluckiger M., Feige K. \& Pospischil A. 2002. Diagnosis by ultrasonography of congestion of the caudal vena cava secondary to thrombosis in 12 cows. Vet. Rec. 150(7):209-213. <https://dx.doi.org/10.1136/vr.150.7.209> <PMid:11878438>

Braun U., Schefer U., Gerber D. \& Föhn J. 1992. Ultrasonographic findings in a cow with ascites due to thrombosis of the caudal vena cava. Schweiz. Arch. Tierheilkd. 134(5):235-241. <PMid:1641617>

Braun U., Stettler M., Schramm S. \& Hilbe M. 2016. Ascites secondary to compression of the caudal vena cava by liver abscesses in a cow. J. Vet. Sci. Anim. Husb. 4(1):1-7. <https://dx.doi.org/10.15744/2348-9790.4.105>

Breeze R.G. \& Petrie L. 1977. Thrombosis of the cranial vena cava in a cow. Vet. Rec. 101(7):130-131. <https://dx.doi.org/10.1136/vr.101.7.130> <PMid:919301>

Breeze R.G., Pirie H.M., Selman I.E. \& Wiseman A. 1976. Pulmonary arterial thromboembolism and arterial mycotic aneurysm in cattle with vena caval thrombosis: condition resembling the Hughes-stovin syndrome. J. Pathol. 119(4):229-237.<https://dx.doi.org/10.1002/path.1711190407> $<$ PMid:989055>

Carneiro C., Schwertz C.I., Henker L.C., Rhoden L.A., Piva M.M., Gabriel M.E., Lucca N.J., Baldi K.R.A., Casagrande R.A., Gomes T.M.A. \& Mendes R.E. 2019. Doenças diagnosticadas pelo Laboratório de Patologia Veterinária no Quinquênio 2013-2017. Bol. Diagn. Lab. Patol. Vet., IFC Concórdia, 2(1):516. <https://dx.doi.org/10.21166/bdpatvet.v2i1.516>

Constable P.D., Hinchcliff K.W., Done S.H. \& Grunberg W. 2017. Veterinary Medicine: a textbook of the diseases of cattle, horses, sheep, pigs, and goats. 11th ed. Elsevier, St. Louis. 2278p.

Dirksen G. 1993. Sistema digestivo, p.166-228. In: Dirksen G., Gründer H.D. \& Stöber M. (Eds), Rosenberger Exame Clínico dos Bovinos. 3rd ed. Guanabara Koogan, Rio de Janeiro.

Facury Filho E.J., Carvalho A.U., Ferreira P.M. \& Aquino Neto H.M. 2007. Trombose de veia cava caudal em bovinos: relato de caso. Arch. Vet. Sci. 12(Supl.):2-4.

Gerspach C., Wirz M., Schweizet-Knubben G. \& Braun U. 2011. Thrombosis of the cranial vena cava in a cow with bronchopneumonia and traumatic reticuloperitonitis. Can. Vet. J. 52(11):1228-1231. <PMid:22547845>
Gudmundson J., Radostits O.M. \& Doige C.E. 1978. Pulmonary thromboembolism in cattle due to thrombosis of posterior vena-cava associated with hepatic abscessation. Can. Vet. J. 19(11):304-309. <PMid:747824>

Jain N.C. 1986. Hematologic techniques, p.20-86. In: Schalm O.W. \& Jain N.C. (Eds), Schalm's Veterinary Hematology. 4th ed. Lea and Febiger, Philadelphia.

Krammer J.N. 2000. Normal hematology of cattle, sheep and goats, p.10751084. In: Feldman B.F., Zinkl J.G. \& Jain N.C. (Eds), Schalm's Veterinary Hematology. 5th ed. Lippincott Willians and Wilkins, Philadelphia.

Luna S.P.L. \& Teixeira M.W. 2007. Eutanásia: considerações éticas e indicações técnicas. Revta CFMV 13(41):60-69.

Mills L.L. \& Pace L.W. 1990. Caudal vena caval thrombosis in a cow. JAVMA 196(8):1294-1296. <PMid:2332379>

Mohamed T., Sato H., Kurosawa T. \& Oikawa S. 2004. Ultrasonographic localization of thrombi in the caudal vena cava and hepatic veins in a heifer. Vet. J. 168(1):103-106. <https://dx.doi.org/10.1016/S10900233(03)00076-5><PMid:15158216>

Monlux W.S. 1962. Ruptured hepatic abscesses in cattle. Iowa State University Veterinarian 24(1):13-15

Motta R.G., Motta I.G., Martinez A.C., Silva A.V., Paes A.C., Martins L.S.A., Silva R.C. \& Ribeiro M.G. 2016. Unusual caudal vena cava thrombosis in a cow, secondary to Trueperella (Arcanobacterium) pyogenes infection. Pesq. Vet. Bras. 36(7):584-590. <https://dx.doi.org/10.1590/S0100736X2016000700004>

Nagaraja T.G. \& Lechtenberg K.F. 2007. Acidosis in feedlot cattle. Vet. Clin. N. Am., Food Anim. Pract. 23(2):333-350. <https://dx.doi.org/10.1016/j. cvfa.2007.04.002 > <PMid:17606155>

Peek S.F. \& Divers T.J. 2018. Rebhun's Diseases of Dairy Cattle. 2nd ed. Elsevier Saunders, St. Louis, p.704.

Plaizier J.C., Krause D.O., Gozho G.N. \& Mcbride B.W. 2008. Subacute ruminal acidosis in dairy cows: the physiological causes, incidence and consequences. Vet. J. 176(1):21-31. <https://dx.doi.org/10.1016/j.tvjl.2007.12.016> <PMid:18329918>

Santos J.F., Silva J.R.B., Souto R.J.C., Silva N.A.A., Souza J.C.A., Afonso J.A.B., Costa N.A., Mendonça C.L., Cajueiro J.F.P. \& Coutinho L.T. 2015. Trombose da veia cava caudal em bovinos. Proc. XI Congresso Brasileiro de Buiatria, São Paulo, São Paulo. (Resumo)

Selman I.E., Wiseman A., Petrie L., Pirie H.M. \& Breeze R.G. 1974. A respiratory syndrome in cattle resulting from thrombosis of the posterior vena cava. Vet. Rec. 94(20):459-466. <https://dx.doi.org/10.1136/vr.94.20.459> <PMid:4850282>

Simpson K.M., Streeter R.N., Cramer S., Lamm C.G. \& Love B.C. 2012. Caudal vena caval thrombosis following treatment of deep digital sepsis. Can. Vet. J. 53(2):182-186. <PMid:22851781>

Tharwat M. 2010. Diagnostic ultrasonography in cattle with caudal vena cava thrombosis. J. Agricult. Vet. Sci. 3(2):111-125.

Vechiato T.A.F., Maschio W., Bom L.C., Lopes P.D. \& Ortolani E.L. 2011. Estudo retrospectivo de abscessos hepáticos em bovinos abatidos em um frigorífico paulista. BJVRAS 48(5):384-391. <https://dx.doi.org/10.11606/S141395962011000500005>

Wilkins P.A. \& Woolums A.R. 2015. Diseases of the respiratory system, p.461-637. In: Smith B.P. (Ed.), Large Animal Internal Medicine. 5th ed. Elsevier Saunders, St. Louis. 